\title{
Genome size of three Brazilian flies from the Sciaridae family
}

\author{
Cecília Ferreira Saccuti ${ }^{1}$, Maria Albertina de Miranda Soares ${ }^{2}$, José Ricardo Penteado Falco ${ }^{1}$ \\ and Maria Aparecida Fernandez ${ }^{1}$ \\ ${ }^{1}$ Universidade Estadual de Maringá, Departamento de Biologia Celular e Genética, Maringá, \\ PR, Brazil. \\ ${ }^{2}$ Universidade Estadual de Ponta Grossa, Departamento de Biologia Estrutural, Molecular e Genética, \\ Ponta Grossa, PR, Brazil.
}

\begin{abstract}
We determined the genome size of the Brazilian sciarid flies Bradysia hygida, Rhynchosciara americana and Trichosia pubescens (Diptera: Sciaridae) using absorbance measurements of Feulgen-stained nuclei belonging to these species (and chicken erythrocytes as a standard) to calculate the amount of DNA in picograms (pg) and the number of base pairs (bp), or C-value, for each of these species. The C-values were: $3 \times 10^{8} \mathrm{bp}(0.31 \mathrm{pg})$ for $B$. hygida; $3.6 \times 10^{8} \mathrm{bp}(0.37 \mathrm{pg})$ for $R$. americana; and $1 \times 10^{9} \mathrm{bp}(1.03 \mathrm{pg})$ for $T$. pubescens. The sciarids investigated in this work had considerably higher $\mathrm{C}$-values than the average for previously described dipteran species, including $D$. melanogaster.
\end{abstract}

Key words: genome size, Feulgen reaction, Sciaridae, Bradysia hygida, Rhynchosciara americana, Trichosia pubescens, Brazilian flies.

Received: March 15, 2004; Accepted: March 22, 2005.

The determination of the genome size of an organism not only provides important data relevant to both the classification of the organism and for comparative studies of the structural genome and evolution (Hardie et al., 2002) but is also useful in molecular biology studies such as the development of genome sequencing strategies.

In haploid genomes the amount of DNA (C-Value) is a unique characteristic of each species. The $\mathrm{C}$-value is given in base pairs (bp) and can range from $10^{5}$ to $10^{7} \mathrm{bp}$ in prokaryotes and from $10^{7}$ to $10^{11} \mathrm{bp}$ in eukaryotes. Although this variation occurs, it is difficult to establish a relationship between the haploid genome size and the morphological, physiological or developmental complexity of an organism (Lozovskaya et al., 1999), this problem originally being known as the $\mathrm{C}$-value paradox but was subsequently renamed to the C-value enigma (Gregory, $2002 ; 2003)$. The sequencing of several genomes has also shown that the gene number does not correlate with the organism complexity (the G-value paradox), which can be explained by several events such as gene redundancy, alternative splicing and post-translational modifications (Hahn and Wray, 2002).

Send correspondence to Maria Aparecida Fernandez. Universidade Estadual de Maringá, Departamento de Biologia Celular e Genética, Av. Colombo 5790, 87020-900 Maringá, PR, Brazil. E-mail: mafernandez@uem.br.
Birds, reptiles and mammals display only a small variation in the DNA content within classes, with the genome size of birds being the most conserved (Tiersch and Wachtel, 1991). However, in amphibians, fish and insects there is a wide variation in $\mathrm{C}$-values between species whose apparent complexity does not vary greatly.

Among the insects whose genome size has already been determined, Drosophila melanogaster presents a compact genome of $1.8 \times 10^{8} \mathrm{bp}$ (Adams et al., 2000) while the haploid DNA content of the fly Aedes albopictus is about sixfold larger (Lengyel and Penman, 1975), with Laupala crickets having a genome size eleven times larger than Drosophila (Petrov and Hartl, 2000) and Podisma pedestris, the brown mountain grasshopper, a haploid genome size of $1.8 \times 10^{10} \mathrm{bp}$ (Bensasson et al., 2001), the largest genome size yet reported for insects (Gregory, 2001).

In general, the known genome sizes cover only a small fraction of the total of species in each class, genome sizes having been estimated in only $2 \%$ of birds, $3 \%$ of fishes, $4 \%$ of reptiles, $7 \%$ of mammals and $8 \%$ of amphibians (Gregory, 2002). The invertebrates constitute the major form of multicellular life but the genome size of only about 1,300 invertebrate species is available in Gregory's Animal Genome Size Database (Gregory 2001). For Diptera, the genome size has been described for only 12 families, 
mainly Drosophilidae and Cullicidae, but no data is available for other dipteran families such as the Sciaridae although insects of this family have been widely used in molecular and cell biology research (Fiorini et al., 2001; Basso Jr. et al., 2002; Monesi et al., 2003; Soares et al., 2003) and the description of their genome size is not only important in these research areas but it could also help in the solution of evolutionary questions relating to the Diptera. The aim of the study presented in this paper was to contribute to the data on insect genome size by determining the DNA content and the genome size of the Brazilian sciarids Bradysia hygida, Rhynchosciara americana and Trichosia pubescens using absorbance measurements of Feulgen-stained neuroblast nuclei from larvae of these species.

The sciarid Bradysia hygida (Sauaia and Alves, 1968) has been reared since 1995 at the Departamento de Biologia Celular e Genética at the Universidade Estadual de Maringá, Paraná, Brazil, according to the conditions described by Laicine et al. (1984) and da Conceição Silva and Fernandez (2000). At $20^{\circ} \mathrm{C}$ B. hygida has a 36-day life cycle. During the larval stage of which three molts occur delimiting four instars, the larval eyespots appearing at the sixth day of the fourth instar and are a useful marker to determine larval age and establish the different developmental stages on this instar (Laicine et al., 1984). In our investigation we used E5 aged female larvae. The $B$. hygida genome is partitioned into four chromosome pairs (A, B, C and $\mathrm{X}$ ), males being $\mathrm{X} 0$ and females XX (Borges et al., 2000).

At $20^{\circ} \mathrm{C}$ Rhynchosciara americana (Breuer, 1967) has a 60-day life cycle with three molts delimiting four instars which have no visible eyespots, because of which the developmental stages during the fourth instar have to be established by changes in the communal cocoon which initially consists of a loose and transparent net but gradually changes to a more solid and white structure due to calcium carbonate deposition. Because this species only survives for three generations under laboratory conditions we collected $R$. americana larvae in the field and maintained them at $20^{\circ} \mathrm{C}$ for one generation using the same diet as for $B$. hygida (Laicine et al., 1984; da Conceição Silva and Fernandez, 2000). For our study we sacrificed the $R$. americana larvae during the $3 \mathrm{~A}$ period (Yokosawa et al., 1999) just before the onset of DNA amplification which in this species occurs during the fourth instar.

We obtained Trichosia pubescens (Morgante, 1969) from a larvae culture originally collected in 1973 at Mogi das Cruzes, São Paulo, Brazil (Amabis, 1983), a permanent culture of this fly being maintained by Dr. Eliana Dessen (Instituto de Biociências, Universidade de São Paulo, São Paulo, Brazil). The life cycle and instar stages of $T$. pubescens are similar to those described above for $B$. hygida, and for our investigation we used 19-day old L5 larvae.
Reference slides for our study were made using cells from 5-day old chickens (Gallus domesticus) obtained from a commercial animal house in Maringá city.

For neuroblast nuclei preparations, brains of E5 aged female $B$. hygida larvae, 3A period $R$. americana, and L5 $T$. pubescens were dissected in $50 \mu \mathrm{L}$ of $0.7 \%$ (w/v) aqueous sodium chloride under a stereo microscope and processed as described by Borges et al. (2000) and Gaspar et al. (2002). Briefly, 10 larvae brains were transferred to a $5 \mathrm{~mL}$ petri dish with $1 \%(\mathrm{w} / \mathrm{v})$ hypotonic aqueous trisodium citrate for $10 \mathrm{~min}$, changing the solution once during this time. The brains were then fixed in 3:1 methanol:acetic acid for $1 \mathrm{~h}$ at room temperature and the fixative changed at $15 \mathrm{~min}$ intervals. After fixation slides were prepared by transferring two brains to a slide and squash mounting them in a drop of $45 \%(\mathrm{v} / \mathrm{v})$ aqueous acetic acid under a coverslip, which was subsequently removed by freezing the slide in liquid nitrogen and flipping the coverslip off with a razor blade. The slides were then fixed again in 3:1 ethanol:acetic acid for one hour at $4{ }^{\circ} \mathrm{C}$, air dried and stored at $4{ }^{\circ} \mathrm{C}$ until staining.

Chicken erythrocytes slides were obtained as described by Falco et al., (1999). Briefly, $10 \mathrm{~mL}$ of blood was collected in $2 \mathrm{~mL}$ of $0.9 \%$ (w/v) aqueous sodium chloride supplemented with $0.24 \mathrm{M}$ EDTA and slides prepared by the spread method. The chicken erythrocytes slides were fixed in 3:1 ethanol: acid acetic for $1 \mathrm{~min}$ for the B. hygida and $R$. americana experiments or $1.75 \%$ paraformaldeyde $/ 0.1 \%$ glutaraldeyde in $0.1 \mathrm{M}$ phosphate buffer $\mathrm{pH}$ 7.4 for $15 \mathrm{~min}$ for the T. pubescens experiments, washed in $70 \%$ (v/v) aqueous ethanol for $5 \mathrm{~min}$, air dried and stored at $4{ }^{\circ} \mathrm{C}$ until staining.

All staining procedures were performed at the same time and with the same solutions for each group. The slides were hydrated in 50\%,30\%, 10\% (v/v) ethanol and distilled water (5 min at each concentration) and DNA depurinization carried out in $4 \mathrm{~N}$ hydrochloric acid at $25{ }^{\circ} \mathrm{C}$ for $25 \mathrm{~min}$ (established previously, data not shown). The slides were then washed in distilled water for one minute and stained with Schiff's reagent for $30 \mathrm{~min}$ at $25^{\circ} \mathrm{C}$. After staining, the slides were incubated in two changes of sulphurous water for a total of $30 \mathrm{~min}$, after which the preparations were washed three times in distilled water for $2 \mathrm{~min}$, dehydrated in serial baths of $50 \%, 70 \%$, and absolute ethanol and finally incubated for $2 \mathrm{~min}$ in 1:1 ethanol:xylol and then pure xylol. The preparations were then covered with a coverslip in immersion oil.

Images of the B. hygida; $R$. americana and $T$. pubescens neuroblast nuclei and $G$. domesticus erythrocyte nuclei were captured using a Axiophot Zeiss photomicroscope fitted with a 100x oil-immersion objective, polychromatic light source and a DXC107-A Sony camera using Snappy 3.0 software (Play Inc.). The images were analyzed using the free UTHSCSA ImageTool program developed at the University of Texas Health Science Center at 
San Antonio, Texas and available from the Internet by anonymous FTP (ftp://maxrad6.uthscsa.edu). This tool allowed us to measure the gray values of each nucleus, the resulting integrated densitometry data being analyzed using Microsoft ${ }^{\circledR}$ Excell $^{\circledR}$ software.

The determination of the genome size of the sciarids $B$. hygida, R. americana and T. pubescens was performed by absorbance measurements of Feulgen-stained nuclei, this study being performed in three groups (B. hygida (group 01), R. americana (group 02), and T. pubescens (group 03) with a set of $G$. domesticus slides being processed at the same time.

Slide images were captured and the nuclei FeulgenDNA integrated optical density (Feulgen-DNA IOD) determined, the mean and standard deviation of which are shown in Table 1. These data allowed us to determine the $\mathrm{C}$-value and the genome size using simple calculations. The $\mathrm{C}$-value of $G$. domesticus is well known and contains $1.25 \mathrm{pg}$ of DNA (Smith and Burt, 1998). The comparison between the Feulgen-DNA IOD of the sciarids and $G$. domesticus resulted in a $\mathrm{C}$-value of 0.31 picograms of DNA for $B$. hygida, 0.37 for $R$. americana and 1.03 for T. pubescens. (Table 2). The next step was to convert these values to base pair. According to Dolezel et al. (2003), the number of base pairs is equivalent to the mass in picograms multiplied by $0.978 \times 10^{9}$. The processed data resulted in a genome size of $3 \times 10^{8} \mathrm{bp}$ for $B$. hygida, $3.6 \times 10^{8} \mathrm{bp}$ for $R$. americana, and $1 \times 10^{9} \mathrm{bp}$ for $T$. pubescens.

Fluorescence DNA quantification analysis of $B$. hygida salivary gland polytene nuclei from larvae at the end of the larval stage (Paçó-Larson, 1976) showed values con-
Table 1 - Mean Feulgen-DNA integrated optical density (IOD) values and standard deviation (SD) for Bradysia hygida, Rhynchosciara americana, Trichosia pubescens and Gallus domesticus.

\begin{tabular}{lcc}
\hline Group/ organism & Number of nuclei analyzed & Mean IOD (SD) \\
\hline Group 1 & 1,194 & \\
B. hygida & 585 & $0.0622(0.0107)$ \\
G. domesticus & & $0.2480(0.0872)$ \\
\hline Group 2 & 310 & \\
R. americana & 470 & $0.0926(0.0001)$ \\
G. domesticus & & $0.3092(0.0007)$ \\
\hline Group 3 & 717 & \\
T. pubescens & 757 & $0.1906(0.0110)$ \\
G. domesticus & & $0.2316(0.0477)$ \\
\hline
\end{tabular}

sistent with ours. During larval development $B$. hygida polytene nuclei undergo 12 replication cycles plus an additional replication for the $\mathrm{S} 1$ gland region ( $21 \%$ more DNA) that results in a DNA content of $3 \mathrm{ng}$. If the B. hygida diploid genome DNA content obtained by us $(0.62 \mathrm{pg}$, equivalent to $6.2 \times 10^{-4} \mathrm{ng}$ ) is submitted 12 replication cycles plus an additional $21 \%$ replication the final result is the same value as that reported by Paçó-Larson (1976) for polytene nuclei.

The previous name for $R$. americana was Rhynchosciara angelae, and determination of the $R$. angelae genome size by indirect methods (Balsamo et al., 1973) showed a smaller genome size than that calculated by us. Results from biochemical analysis revealed a genome

Table 2 - C-value of some representative Diptera species.

\begin{tabular}{|c|c|c|c|c|c|c|}
\hline Family & Organism & C-value (pg) & Method & Cell type & Standard & Reference \\
\hline Anthomyiidae & Delia antiqua & 0.73 & FD & $\mathrm{NS}(\mathrm{V})$ & NS & Hartman and Southern, 1995 \\
\hline Calliphoridae & Calliphora erytrocephala & 0.65 & FD & SP & MD & Bier and Müller, 1969 \\
\hline Cecidomyiidae & Mayetiola destructor & 0.09 & NS & NS & NS & Ma et al., 1992 \\
\hline Chaoboridae & Chaoborus americanus & 0.40 & FD & SP & GD & Rao and Rai, 1990 \\
\hline Chironomidae & Chironomus tentas & 0.25 & $\mathrm{BCA}$ & SG & - & Daneholt and Edström, 1967 \\
\hline Culicidae & Aedes aegypti & 0.81 & FD & $\mathrm{SP}$ & GD & Rao and Rai, 1987 \\
\hline Dixidae & Dixa obscura & 0.16 & FD & TS & MD & Jost and Mameli, 1972 \\
\hline Drosophilidae & Drosophila melanogaster & 0.18 & FD & $\mathrm{HC}, \mathrm{SP}$ & GD & Rasch et al., 1971 \\
\hline Muscidae & Musca domestica & 1.04 & NS & NS & NS & Petitpierre, 1996 \\
\hline Psychodidae & Telmatoscopus meridionalis & 0.24 & FD & TS & MD & Jost and Mameli, 1972 \\
\hline Sarcophagidae & Sarcophaga bullata & 0.76 & FD & $\mathrm{TS}$ & GD & Samols and Swift, 1979 \\
\hline Sciaridae & Bradysia hygida & 0.31 & FD & $\mathrm{BR}$ & GD & Present paper \\
\hline Sciaridae & Rhynchosciara americana & 0.37 & FD & $\mathrm{BR}$ & GD & Present paper \\
\hline Sciaridae & Trichosia pubescens & 1.03 & FD & $\mathrm{BR}$ & GD & Present paper \\
\hline Simuliidae & Prosimulium multidentatum & 0.19 & $\mathrm{BCA}$ & WB & - & Sohn et al., 1975 \\
\hline
\end{tabular}

Method: FD, Feulgen densitometry; BCA, biochemical analysis; NS, not specified. Cell type: BR, brain cells; SG, salivary gland; SP, sperm; TS, testis; WB, whole body; V, various; HC, haemocytes; NS, not specified. Standard: GD, Gallus domesticus, 1.25 pg; MD, Musca domestica, 0.9 pg; NS, not specified. Modified from Gregory (2001). 
size of $2.1 \times 10^{8}$ bp (Balsamo et al., 1973) but since the value of the $E$. coli genome used as reference was $4 \times 10^{6} \mathrm{bp}$ and not $4.7 \times 10^{6} \mathrm{bp}$ (Blattner et al., 1997) the $R$. americana genome may be larger than previously described.

There is no data in the literature on the polytene nucleus content of $T$. pubescens that could be compared to our results. However, the amount of DNA in the nuclei of different tissues of Sciara coprophila was determined by cytospectrophotometry to be about 2 pg by Rasch (1970).

The sciarids used in our work present considerably greater $\mathrm{C}$-values than the average $\mathrm{C}$-values of representatives dipteran species already described and also greater than the genome size $(0.18 \mathrm{pg})$ of the model organism $D$. melanogaster (Table 2; Gregory, 2001). It is interesting to note that the largest $\mathrm{C}$-values in Table 2 are for $T$. pubescens and Musca domestica.

Only a small number of sequences of the total genome is involved in coding and there is a considerable presence of non-coding sequences such as pseudogenes, transposable elements and repetitive sequences in general (Petrov, 2001; Prokopowich et al., 2003). According to Hancock (2002), transposable elements and the accumulation of repetitive sequences are the main genetic mechanisms responsible for variations in genome size.

The reported size of a genome can be affected by other genetic mechanisms such as, mutation components, e.g. polyploidy, fixation of accessory chromosomes, large duplications or chromosome deficiencies (Lozovskaya et al., 1999; Petrov et al., 2000). The genetic mechanisms contributing to the $\mathrm{C}$-value paradox can sometimes be classified as selection components, e.g., a genome cannot be smaller than the necessary size needed to include all the essential genes, nor can it be so big as to require excess energy to maintain itself (Lozovskaya et al., 1999).

Petrov et al. (2000) have pointed out that in evolutionary terms variations in genome size can be explained by assuming that organisms with larger genomes have exhibited low rates of DNA elimination over thousands of years. This extra DNA has functions such as codification of proteins or participation on the direct regulation of that process, or even unknown function (Kimura et al., 2001).

The importance of the gene number (G-value) has been reported in some studies (Betrán and Long, 2002). It is known that Aedes albopictus has 6 times more DNA than D. melanogaster although both species present the same level of gene expression, with 3,000 to 4,000 mRNA sequences having been observed in cultured cells of both of these species (Lengyel and Penman, 1975). Such data supports the G-value paradox, which states that the genome size is independent of the number of coding sequences.

The high DNA content observed by us in the genomes of the sciarids $B$. hygida, $R$. americana and T. pubescens is interesting and needs to be investigated, possibly by the analysis of repeated sequences.

\section{Acknowledgments}

We thank Valmir Peron and Marli Licero Schuete Silva for their dedicated technical assistance with the culture of $B$. hygida and T. pubescens. We are also grateful to Dr. Eliana Maria Beluzzo Dessen (Universidade de São Paulo) for the T. pubescens larvae and Márcia Graeff (Faculdade de Medicina de Ribeirão Preto, USP) for microscopy facilities. CFS receives a graduate fellowship from the Brazilian agency Conselho Nacional de Desenvolvimento Tecnológico (CNPq). This work was supported by grants from $\mathrm{CNPq}$, Fundação Araucária and The Third World Academy of Sciences (TWAS).

\section{References}

Adams MD, Celniker SE, Holt RA, Evans CA, Gocayne JD, Amanatides PG, Scherer SE, Li PW, Hoskins RA, Galle RF, George RA, Lewis SE, Richards S, Ashburner M, Henderson SN, Sutton GG, Wortman JR, Yandell MD, Zhang Q, Chen LX, Brandon RC, Rogers YH, Blazej RG, Champe M, Pfeiffer BD, Wan KH, Doyle C, Baxter EG, Helt G, Nelson CR, Gabor GL, Abril JF, Agbayani A, An HJ, Andrews-Pfannkoch C, Baldwin D, Ballew RM, Basu A, Baxendale J, Bayraktaroglu L, Beasley EM, Beeson KY, Benos PV, Berman BP, Bhandari D, Bolshakov S, Borkova D, Botchan MR, Bouck J, Brokstein P, Brottier P, Burtis KC, Busam DA, Butler H, Cadieu E, Center A, Chandra I, Cherry JM, Cawley S, Dahlke C, Davenport LB, Davies P, de Pablos B, Delcher A, Deng Z, Mays AD, Dew I, Dietz SM, Dodson K, Doup LE, Downes M, Dugan-Rocha S, Dunkov BC, Dunn P, Durbin KJ, Evangelista CC, Ferraz C, Ferriera S, Fleischmann W, Fosler C, Gabrielian AE, Garg NS, Gelbart WM, Glasser K, Glodek A, Gong F, Gorrell JH, Gu Z, Guan P, Harris M, Harris NL, Harvey D, Heiman TJ, Hernandez JR, Houck J, Hostin D, Houston KA, Howland TJ, Wei MH, Ibegwam C, Jalali M, Kalush F, Karpen GH, Ke Z, Kennison JA, Ketchum KA, Kimmel BE, Kodira CD, Kraft C, Kravitz S, Kulp D, Lai Z, Lasko P, Lei Y, Levitsky AA, Li J, Li Z, Liang Y, Lin X, Liu X, Mattei B, McIntosh TC, McLeod MP, McPherson D, Merkulov G, Milshina NV, Mobarry C, Morris J, Moshrefi A, Mount SM, Moy M, Murphy B, Murphy L, Muzny DM, Nelson DL, Nelson DR, Nelson KA, Nixon K, Nusskern DR, Pacleb JM, Palazzolo M, Pittman GS, Pan S, Pollard J, Puri V, Reese MG, Reinert K, Remington K, Saunders RD, Scheeler F, Shen H, Shue BC, Siden-Kiamos I, Simpson M, Skupski MP, Smith T, Spier E, Spradling AC, Stapleton M, Strong R, Sun E, Svirskas R, Tector C, Turner R, Venter E, Wang AH, Wang $X$, Wang ZY, Wassarman DA, Weinstock GM, Weissenbach J, Williams SM, WoodageT, Worley KC, Wu D, Yang S, Yao QA, Ye J, Yeh RF, Zaveri JS, Zhan M, Zhang G, Zhao Q, Zheng L, Zheng XH, Zhong FN, Zhong W, Zhou X, Zhu S, Zhu X, Smith HO, Gibbs RA, Myers EW, Rubin GM, Venter JC. (2000) The genome sequence of Drosophila melanogaster. Science 287:2185-2195.

Amabis JM (1983) The polytene chromosomes of the salivary gland of Trichosia pubescens (Diptera, Sciaridae). Rev Bras Genet 7:415-424.

Balsamo J, Hierro JM, Birnstiel ML and Lara FJ (1973) Rhynchosciara angelae salivary gland DNA: Kinetic com- 
plexity and transcription of repetitive sequences. Basic Life Sci 1:101-122.

Basso Jr LR, Vasconcelos C, Fontes AM, Hartfelder K, Silva JA Jr, Coelho PS, Monesi N and Paçó-Larson ML (2002) The induction of DNA puff $B h C 4-1$ gene is a late response to the increase in 20-hydroxyecdysone titers in last instar dipteran larvae. Mech Dev 110:15-26.

Bensasson D, Petrov DA, Zhang DX, Hartl DL and Hewitt GM (2001) Genomic gigantism: DNA loss is slow in mountain grasshoppers. Mol Biol Evol 18:246-253.

Betrán E and Long M (2002) Expansion of genome coding regions by acquisition of new genes. Genetica 115:65-80.

Bier K and Müller W (1969) DNA-Messungen bei Insekten und eine Hypothese über retardierte Evolution und besonderen DNA-Reichtum in Tierreich. Biologisches Zentralblatt 88:425-449.

Blattner FR, Plunkett G 3rd, Bloch CA, Perna NT, Burland V, Riley M, Collado-Vides J, Glasner JD, Rode CK, Mayhew GF, Gregor J, Davis NW, Kirkpatrick HA, Goeden MA, Rose DJ, Mau B and Shao Y (1997) The complete genome sequence of Escherichia coli K-12. Science 277:1453-1474.

Borges AR, Gaspar VP and Fernandez MA (2000) Unequal X chromosomes in Bradysia hygida (Diptera, Sciaridae) females: Karyotype assembly and morphometric analysis. Genetica 108:101-105.

Breuer ME (1967) Cromossomos politênicos das glândulas salivares de Rhynchosciara angelae. Rev Bras Biol 27:105-108.

da Conceição Silva JL and Fernandez MA (2000) Feulgen stain in heterogeneous egg samples from non-synchronized Bradysia hygida (Diptera, Sciaridae) laboratory culture. Cytologia 65:167-171.

Daneholt B and Edström JE (1967) The content of deoxyribonucleic acid in individual polytene chromosomes of Chironomus tentans. Cytogenetics 6:350-356.

Dolezel J, Bartos J, Voglmayr H and Greilhuber J (2003) Nuclear DNA content and genome size of trout and human. Cytometry 51A:127-128.

Falco JRP, Mello MLS, Maria SS and Grazziotin NA (1999) Critical electrolyte concentration of chicken erythrocyte chromatin. Acta Histochem Cytochem 32:73-76.

Fiorini A, Basso Jr LR, Paçó-Larson ML and Fernandez MA (2001) Mapping of intrinsic bent DNA Sites in the upstream region of DNA puff $B h C 4-1$ amplified gene. J Cell Biochem $83: 1-13$

Gaspar VP, Borges AR and Fernandez MA (2002) NOR sites detected by Ag-DAPI staining of an unusual autosome chromosome of Bradysia hygida (Diptera, Sciaridae). Genetica114:57-61.

Gregory TR (2001) Animal Genome Size Database. http://www. genomesize.com/. Last accessed: [01/23/2004].

Gregory TR (2002) Genome size and developmental complexity. Genetica 115:131-146.

Gregory TR (2003) Is small indel bias a determinant of genome size? Trends Genet 19:485-488.

Hahn MW and Wray GA (2002) The g-value paradox. Evol Dev 4:73-75.

Hancock JM (2002) Genome size and the accumulation of simple sequence repeats: Implications of new data from genome sequencing projects. Genetica 115:93-103.

Hardie DC, Gregory TR and Hebert PDN (2002) From pixels to picograms: A beginners' guide to genome quantification by
Feulgen image analysis densitometry. J Histochem Cytochem 50:735-749.

Hartman TP and Southern DI (1995) Genome reorganization from polyteny to polyploidy in the nurse cells found in onion fly (Delia antiqua) and cabbage root fly (Delia radicum) ovaries (Diptera, Anthomyiidae). Chromosome Res 3:271-280.

Jost E and Mameli M (1972) DNA content in nine species of Nematocera with special reference to the sibling species of the Anopheles maculipennis group and the Culex pipiens group. Chromosoma 37:201-208.

Kimura RH, Choudary PV, Stone KK and Schmid CW (2001) Stress induction of Bm1 RNA in silkworm larvae: SINEs, an unusual class of stress genes. Cell Stress Chaperones 6:263272.

Laicine EM, Alves MAR, De Almeida JC, Rozzo E, Albernaz WC and Sauaia H (1984) Development of DNA puffs and patterns of polypeptide synthesis in the salivary glands of Bradysia hygida. Chromosoma 89:280-284.

Lengyel J and Penman S (1975) hnRNA size and processing as related to different DNA content in two Dipterans: Drosophila and Aedes. Cell 5:281-290.

Lozovskaya ER, Nurminsky DI, Petrov DA and Hartl DL (1999) Genome size as a mutation - selection - drift process. Genes Genet Syst 74:201-207.

Ma RZ, Black WC and Reese JC (1992) Genome size and organization in an aphid (Schizaphis graminum). J Insect Physiol 38:161-165.

Monesi N, Basso LR Jr and Paçó-Larson ML (2003) Identification of regulatory regions in DNA puff $B h C 4-1$ gene promoter. Insect Mol Biol 12:247-254.

Morgante JS (1969) Tree new species of Brazilian Sciaridae (Diptera, Nematocera). Rev Bras Biol 29:571-576.

Paçó-Larson ML (1976) Análise quantitativa do conteúdo de DNA da glândula salivar de Bradysia hygida. Master Thesis. Faculdade de Medicina de Ribeirão Preto, Universidade de São Paulo, Ribeirão Preto.

Petitpierre E (1996) Molecular cytogenetics and taxonomy of insects, with particular reference to the Coleoptera. International J Insect Morphol \& Embryol 25:115-133.

Petrov DA (2001) Evolution of genome size: New approaches to an old problem. Trends Genet 17:23-28.

Petrov DA and Hartl DL (2000) Pseudogene evolution and natural selection for a compact genome. J Hered 91:221-227.

Petrov DA, Sangster TA, Johnston JS, Hartl DL and Shaw KL (2000) Evidence for DNA loss as a determinant of genome size. Science 287:1060-1062.

Prokopowich CD, Gregory TR and Crease TJ (2003) The correlation between rDNA copy number and genome size in eukaryotes. Genome 46:48-50.

Rao PN and Rai KS (1987) Inter and intraspecific variation in nuclear DNA content in Aedes mosquitoes. Heredity 59:253258.

Rao PN and Rai KS (1990) Genome evolution in the mosquitoes and other closely related members of superfamily Culicoidea. Hereditas 113:139-144.

Rasch EM (1970) DNA cytophotometry of salivary gland nuclei and other tissue systems in dipteran larvae. In: Wied GL and Bahr GF (eds) Introduction to Quantitative Cytochemistry II. 2nd ed. Academic Press, New York, pp 335-355.

Rasch EM, Barr HJ and Rasch RW (1971) The DNA content of sperm of Drosophila melanogaster. Chromosoma 33:1-18. 
Samols D and Swift H (1979) Genomic organization in the flesh fly Sarcophaga bullata. Chromosoma 75:129-143.

Sauaia H and Alves MAR (1968) A description of a new species of Bradysia hygida. Papéis Avulsos de Zoologia 22:85-88.

Smith J and Burt DW (1998) Parameters of the chicken genome (Gallus gallus). Anim Genet 29:290-294.

Soares MA, Monesi N, Basso LR Jr, Stocker AJ, Paçó-Larson ML and Lara FJ (2003) Analysis of the amplification and transcription of the C3-22 gene of Rhynchosciara americana
(Diptera, Sciaridae) in transgenic lines of Drosophila melanogaster. Chromosoma 112:144-151.

Sohn U-I, Rothfels KH and Straus NA (1975) DNA: DNA hybridization studies in black flies. J Mol Evol 5:75-85.

Tiersch TR and Wachtel SS (1991) On the evolution of genome size of birds. J Hered 82:363-368.

Yokosawa J, Soares MA, Dijkwel PA, Stocker AJ, Hamlin JL and Lara FJ (1999) DNA replication during amplification of the C3 puff of Rhynchosciara americana initiates at multiple sites in a $6 \mathrm{~kb}$ region. Chromosoma 108:291-301.

Associate Editor: André Luiz Paranhos Perondini 